\title{
Hydrochemical characterization of thermal waters in Shipkovo thermal field
}

\author{
Aleksey Benderev ${ }^{l}$, Stanimir Stanev ${ }^{2}$, Mila Trayanova ${ }^{l}$, Sava Kolev ${ }^{l}$, \\ Aglaida Toteva ${ }^{1}$
}

${ }^{1}$ Geological Institute, Bulgarian Academy of Sciences, 1113 Sofia, Bulgaria;

e-mail: alekseybenderev@yahoo.com

${ }^{2}$ V. Tarnovo; e-mail: sstanev53@abv.bg

\section{Хидрохимична характерстика на термалните води в находище ,Шипково“6}

\author{
Алексей Бендерев, Станимир Станев, Мила Траянова, Сава Колев, \\ Аглаида Тотева
}

Benderev, A., S. Stanev, M. Trayanova, S. Kolev, A. Toteva. 2019. Hydrochemical characterization of thermal waters in Shipkovo thermal field. Engineering Geology and Hydrogeology, 33, 27-39.

\begin{abstract}
Shipkovo" thermal water field is one of the few in the country formed in karstified carbonate rocks. Initially, there was a natural spring with elevated temperature, located at the boundary of Triassic karstified limestones and dolomites and Lower Cretaceous terrigenous rocks, sinking in depth to the east. Later, drilling operations were carried out in the area, which resulted in the discovery of additional quantities of water with different temperatures and chemical composition, which led to the discovery of additional water of different temperature and chemical composition.

Eight wells were drilled east of the natural spring with a depth from 174 to $1315 \mathrm{~m}$, with thermal waters from different depths found in the Triassic karst aquifer and the fissured Jurassic terrigenous rocks. The characterization of the chemical composition of the waters was made based on 55 water samples analyzes. It is established that the chemical composition is specific to the individual water sources and varies over time. The natural spring is characterized with the most significant fluctuations in the concentrations of some hydrochemical indicators - the maximum and minimum values of the total dissolved solids (TDS) differ approximately twice, and the $\mathrm{pH}-$ by about 2 units. As the flow rate of the spring increases and its temperature decreases, the type of water changes from $\mathrm{HCO}_{3}-\mathrm{SO}_{4}-$ $\mathrm{Ca}-\mathrm{Mg}$ to $\mathrm{HCO}_{3}-\mathrm{Ca}$, and the concentrations of indicators characterizing the deep origin of thermal water decrease - fluorine (from $1.5 \div 1.6$ to $0.1 \div 0.3 \mathrm{mg} / \mathrm{l}$ ) and metasilicic acid (from $20 \div 25$ to 10 $\mathrm{mg} / \mathrm{l})$. In periods when mainly deep mineral water flows from the spring, rather than mixed thermal and atmospheric waters, the concentrations of $\mathrm{Ba}, \mathrm{Sr}, \mathrm{Al}, \mathrm{Li}$ are significantly higher. Comparison of the chemical composition of groundwater from individual wells shows the influence of geological and hydrogeological factors on its formation and changes in depth. The mixing of the waters formed by active water exchange in the karst environment of the Triassic limestones and dolomites with $\mathrm{HCO}_{3}-\mathrm{Ca}$ and $\mathrm{HCO}_{3}-\mathrm{Ca}-\mathrm{Mg}$ type with the water formed in fractured rocks with stagnant character and $\mathrm{SO}_{4}-\mathrm{Ca}-\mathrm{Mg}$ type in the Jurassic deposits and within the reach of the Shipkovo Fault, the fieldspecific $\mathrm{SO}_{4}-\mathrm{HCO}_{3}-\mathrm{Ca}-\mathrm{Mg}$ waters are formed. With respect to the microcomponents, there is a slight tendency to increase the concentration of $\mathrm{F}, \mathrm{Sr}, \mathrm{Ti}, \mathrm{Ba}, \mathrm{Mo}, \mathrm{Ni}, \mathrm{Mn}$ in depth, but in the deepest wells they are relatively lower. The results obtained are useful in support of management decisions for the utilization of thermal waters from the Shipkovo field.
\end{abstract}

Keywords: thermal waters, hydrochemistry, karst waters, Shipkovo. 
Резюме. Находището на термални води „Шипково“ е едно от най-големите в Северна България и е формирано главно в плавно затъващи в дълбочина окарстени триаски варовици и доломити. Първоначално е съществувал естествен контактен извор, като впоследствие са прокарани няколко сондажа, разкриващи води както от триаския водоносен хоризонт, така и пукнатинни води, привързани към юрски теригенни скали и натрошени скали в обсега на Шипковския разлом. Геоложките и хидрогеоложки фактори са основни за формиране на химичния състав. Преобладаващи са $\mathrm{HCO}_{3}-\mathrm{SO}_{4}-\mathrm{Ca}-\mathrm{Mg}_{\text {и }} \mathrm{SO}_{4}-\mathrm{HCO}_{3}-\mathrm{Ca}-\mathrm{Mg}$ води, формирани от смесване на пресни карстови води и по-високо минерализирани води в юрските скали със забавен водообмен. Във водите се установяват и редица микрокомпоненти, някои от които в по-високи концентрации. Получените резултати имат значение за бъдещото използване на термалните води.

Ключови думи: термални води, хидрохимия, карстови води, Шипково.

\section{Въведение}

Находище на термални води „Шипково“ или „Шипковски минерални бани“ е едно от малкото в страната, които са формирани в окарстени карбонатни скали. Първоначално е съществувал естествен извор с повишена температура. По-голяма популярност находището придобива през XX век, когато водата от извора започва да се използва не само от местното население. За увеличаване на дебита му, в района се провеждат сондажни работи, които разкриват допълнителни количества вода с различаваща се температура и химичен състав. Целта на настоящото проучване е да се установят факторите и закономерностите за формиране на водите от находището и особеностите на химичния им състав. Използвани са главно резултати от многобройни досегашни хидрогеоложки проучвания и анализи на взети проби, обобщени при преоценката на хидротермалната енергия в България, извършена за разглеждания район от Станев, Недев (1998ф) ${ }^{1}$.

\section{Геоложки и хидрогеоложки условия}

Хидротермалното находище „Шипково“ е разположено в най-източните части на Васильовска планина, в горните части на долината на р. Ръждавец, ляв приток на р. Бели Осъм (фиг. 1). Районът на находището е на надморска височина между 660 и 740 m, докато околните ридове достигат височини $900-1200 \mathrm{~m}$.

Хидрогеоложките условия в района на Шипково се предопределят главно от геоложкия строеж. В тази част на Централна Стара планина са разпространени мезозойски седиментни скали (Cheshitev et al., 1993, 1994). В района на Шипковските минерални бани и повърхностния им водосбор се разкриват редица литостратиграфски единици, които могат да се групират в 5 хидрогеоложки единици (фиг. 2):

Горноюрско-долнокреден колплекс - В строежа му участват две свити, отделени от Nikolov, Sapunov (1970): Нешковската свита покрива горноюрските карбонатни скали и е изградена от мергели, глинести варовици и варовити глини, с обща дебелина $130-150 \mathrm{~m}$. Покрива се от флишките материали на Черниосъмската свита - непрекъснато редуване на пясъчници, алевролити, мергели, варовици и техните преходи. В профила преобладават мергелите, докато останалите разновидности са в подчинено значение и се прослояват в тях. Дебелината на свитата в района е около 500 - 600 m. Поради преобладаването на глинести и мергелни наслаги, в регионално отношение този комплекс има водоупорен характер. В локално отношение има условия за формиране на

${ }^{1}$ Станев, Ст., Н. Недев. 1998. Хидротермално находище Шипково (Шипковски минерални бани). Отчет по тема „Преоценка на геотермалната енергия в България“. Геологически институт, БАН. 


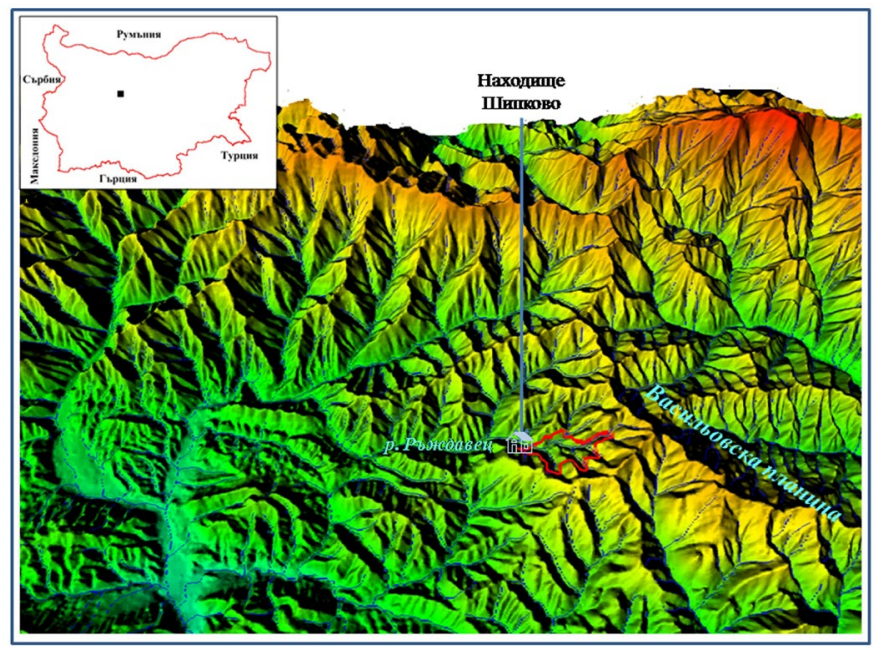

Фиг. 1. Разположение на находище „Шипково“ (с червено са оградени разкритията на триаски карбонатни скали)

Fig. 1. Location of the thermal water field "Shipkovo" (red line delineates outcroppings of the Triassic carbonate rocks)
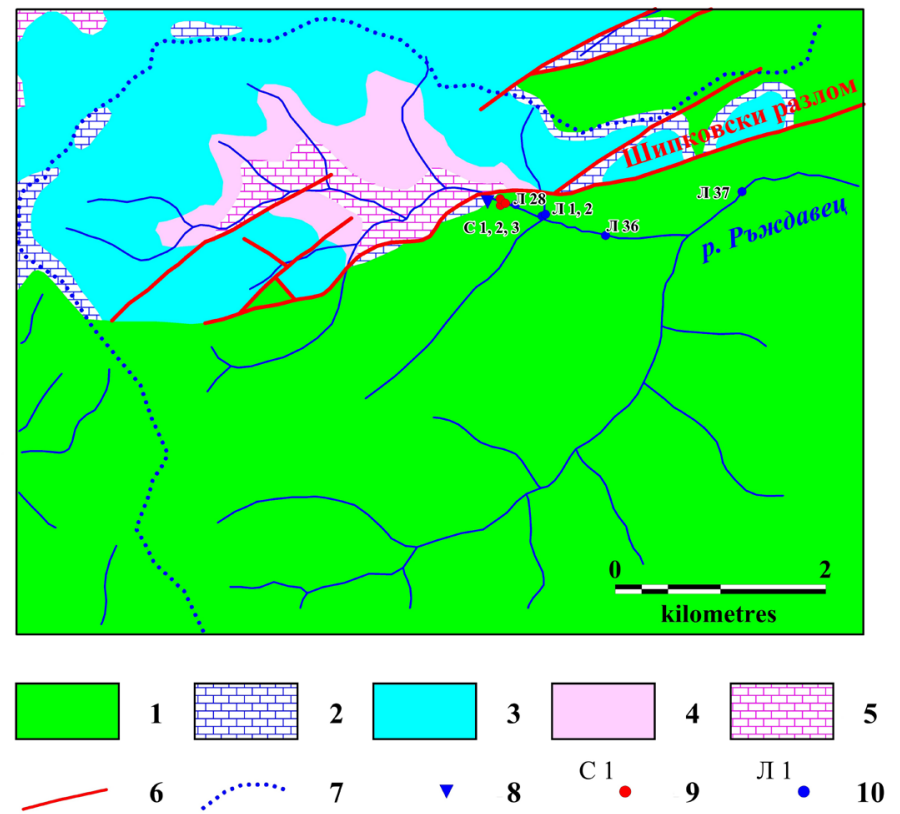

Фиг. 2. Хидрогеоложки единици в района на Шипковски минерални бани:

1 - Горноюрско-долнокреден пукнатинен комплекс; 2 - Средно-горноюрски карстов водоносен хоризонт; 3 - Долно-средноюрски комплекс; 4 - Горнотриаски пукнатинно - карстов комплекс; 5 - Триаски карстов водоносен хоризонт; 6 - Разломно нарушение; 7 - Граница на водосбор на р. Ръждавец; 8 - Шипковски извор; 9 - Сондажи, прокарани от Водоканалпроект; 10 - Сондажи прокарани от ГПП - Ямбол

Fig. 2. Hydrogeological units around the Shipkovo mineral bath:

1 - Upper Jurassic - Lower Cretaceous fissured complex; 2 - Middle-Upper Jurassic karst aquifer; 3 - LowerMiddle Jurassic complex; 4 - Upper Triassic fissure-karst complex; 5 - Triassic karst aquifer; 6 - Fault disturbance; 7 - Boundary of the catchment area of the Razhdavets River; 8 - Shipkovo spring; 9 - Boreholes conducted by Vodokanalproekt; 10 - Boreholes drilled by the Geological exploration company - Yambol 
подземни води в участъци с тектонско въздействие, където скалите са нагънати, напукани, а на места и натрошени, както и в изветрителните зони в непосредствена близост до повърхността. В образувалата се приповърхностна гъста мрежа от тектонски и изветрителни пукнатини се е формирала сложна анизотропна хидравлична система, в която се акумулират и циркулират ненапорни подземни води. Относително по-водоносни са крехките скали - пясъчници и варовици, докато в по-глинестите материали - аргилити, алевролити, мергели, движението на водите е затруднено. Дебелината на водонаситената зона е различна, като е най-голяма в зоните на тектонските нарушения. Подхранването на подземните води е от валежи, а дренирането - от многобройни низходящи извори с дебити от $0,02 \mathrm{l} / \mathrm{s}$, рядко до 0,7 1/s. Поради преобладаващите слабо пропускливи глинести скали, проникването на води от приповърхностния слой в дълбочина, до понапуканите прослойки от пясъчници и варовици е затруднено. То може да се осъществява само в зони на тектонски нарушения, като се формират сложни системи от напорни водонаситени разломни зони с проникващи води във водопропускливите пластове.

Средно-горноюрски карстов водоносен хоризонт. Изграден е от прекристализиралите варовици и песьчливи варовици на Яворецката свита и ядчестите варовици на Гинската свита (Nikolov, Sapunov, 1970) с обща дебелина ненадвишаваща 20-30 m. На повърхността се разкриват в тесни ивици, около периферията на разкритията на долно-средноюрския комплекс, както и като отделни изолирани разкрития в билните части. В тези участъци водите са ненапорни и се насочват към речно-овражната мрежа. По-съществени карстови извори има при х. Коман. В дълбочина този водоносен хоризонт също не е с голяма дебелина.

Долно-средноюрски комплекс. Пространственото му положение съвпада с разпространението на предимно теригенните свити с долно-сердноюрска възраст. Те се отнасят главно към три литостратиграфски свити, отделени от Sapunov et al. (1967). В основата на комплекса е Костинската свита, изградена от конгломерати и кварцитизувани пясъчници с дебелина 4-5 m. Между Костинската свита и лежащите под нея горнотриаски седименти се наблюдава значително ожелезнена размивна повърхнина. Нагоре без рязък преход следва Озировската свита, започваща със слабо песъчливи ожелезнени варовици, които постепенно прехождат в пласт от желязно-карбонатна руда с дебелина 2 m. Над този пласт залягат сивобелезникави нечисти варовици и алевритови глинести аргилити с шамозитови ооли. Общата дебелина в зоните на разкритията на Костинската и Озировската свита не надминава $20 \mathrm{~m}$, а в дълбочина, чрез сондажи, са установени дебелини достигащи до $100 \mathrm{~m}$. Най-отгоре в долно-сердноюрския разрез е разположена Етрополската свита, представена в долната си част от сиви до черни песъчливи аргилити, съдържащи пирит-марказитови и по-малко фосфоритови конкреции, а в горната - кварцови алевролити и пясъчници. Аргилитите обикновено имат водоупорен характер. Общата дебелината на Етрополската свита рядко е по-голяма от $130 \mathrm{~m}$. В зоните на разкритията са формирани пукнатинни води, привързани към зоните на изветряне. Формирани са ненапорни води, които се движат от по-високите към по-ниските части на терена. Изворите са низходящи и се формират най-често на контактите на по-песъчливи с по-глинести наслаги. Дебитите им варират от 0,01 1/s до 1,0 1/s, а температурите от 7,8 до $14,0{ }^{\circ} \mathrm{C}$. Със затъване в дълбочина характерът на комплекса се променя, като той става напорен, пластово-пукнатинен. Относително по-водонаситени са пластовете, изградени предимно от по-крехки материали - пясъчници и варовици, а по-слабо - по-глинести седименти. Най-водообилни са зоните от водоносния комплекс, разположени в близост до разломни нарушения. 
Горнотриаски пукнатинно - карстов комплекс. Скалите, които изграждат този комплекс се отнасят към Мизийската група (Tronkov, 1981), която в изследвания район е неразчленена и има дебелина до 150-160 m. Представени са в основата от сиви и бледорозови варовици, преминаващи в ядчести варовици и керемиденочервени глинести варовици и варовити мергели. Над тях отново са ядчести варовици, покрити от брекчоконгломерати и конгломерати. Присъстващите в разреза карбонатни скали са окарстени, докато в теригенните материали има условия за формиране само на пукнатинни води в напукани и изветрели зони. Често този комплекс се разглежда като част от лежащия под него триаски карбонатен хоризонт.

Триаски карстов водоносен хоризонт. Подземните води са вместени в окарстени карбонатни скали на Искърската група (Tronkov, 1981). В геоложкия профил доминират доломитите, които се прослояват от варовици. Скалите на Искърската карбонатна група са значително напукани, което благоприятства проникването на вода в тях и активизиране на процеси на окарстяване, които са довели до разширяване на пукнатините и образуване на каверни с различни размери и форма. Друга част от пукнатините са запълнени с преотложен калцит. Общата дебелина на водоносния хоризонт е $200-250 \mathrm{~m}$.

За формирането на находище „Шипково“ съществено значение има тектонският строеж, който е определящ за пространственото положение и взаимоотношенията между отделните хидрогеоложки структури. Основната гънкова структура тук е Шипковската антиклинала (Gochev, 1971). Оста ѝ е приблизително със запад - източна посока и съвпада с долината на р. Ръждавец. Ядката ѝ е изградена от триаски седименти, а бедрата от горноюрскодолнокредни скали. Антиклиналната структура е нарушена от редица разломни нарушения, като най-значимото от тях е Шипковският разлом (фиг. 2). Той се проследява много добре на терена в югозапад североизточна посока и представлява разсед - отсед. Широчината на разломната зона е около 30-40 m, като тя затъва под ьгъл 50 на юг. Пропаднала е южната част с амплитуда 700 - $750 \mathrm{~m}$ и хоризонтално отместване около $2,5 \mathrm{~km}$. Той представлява тектонска граница между горноюрско-долнокредния комплекс и карстовите водоносни хоризонти на горната юра и триаса.

\section{Обща характеристика на Шипковски минерални бани}

Съгласно направения от Станев, Недев (1998ф) исторически обзор, първите сведения за съществуване на извор с повишена температура в района са от първата половина на XVII век, когато е основано с. Шипково (1633 г.). Целенасоченото използване на минералната вода датира от 1912 г. и е организирано от Кино Кънчев Пеловски от с. Шипково. Съвременната баня е построена през 1941 година.

През 1939 г. Георги Бончев (Bonchev, 1939) в студията си „Принос към изворите в България. Генезис и топлика“" измерва дебита на Шипковския извор - 190 l/min (около 3,2 1/s). Сведения за находището на минерална вода дава и Azmanov (1940), който съобщава, че дебитът се изменя от 2,5 до около 10 1/s, a температурата - от 19 до $24^{\circ} \mathrm{C}$. Той определя и химичния състав на водата.

Сведения за Шипковската минерална вода се срещат в редица други работи: на Radoslavov (1937), Shterev (1964), Petrov (1964), Vutkov, Petrov (1968), Petrov et al. (1970) и др. Минералният извор е разположен в местността "Баните" и отстои на $50 \mathrm{~m}$ западно от сградата на банята. Водата извира на десния бряг на р. Ръждавец (фиг. 1) от разломените среднотриаски доломити, на границата им с титонски седименти, които също са разломени. Изворът е пукнатиннокарстов с крайно непостоянен режим. През периода 1964 - 1966 година, от "Водоканалпроект" - София са проведени сондажни хидрогеоложки 
проучвания в съседство с естествения минерален извор (Лимонадов, 1965ф)². Прокарани са 3 броя сондажи с различни дълбочини и първоначални дебити на самоизлив и температури (табл. 1, фиг. 2). Следващите проучвания на находището са проведени от ГПП - Ямбол през 1971/84 година, резултатите от които са обобщени от Михайлов (1979ф, 1984ф) ${ }^{3,4}$. Първоначално е сондирано в близост до естествения извор, но впоследствие са прокарани сондажи на изток по долината на р. Ръждавец, съответно на около 300 m (Л-1 и Л-2), 1200 m (Л-36) и $2200 \mathrm{~m}$ (Л-37). От всички сондажи излиза вода на самоизлив. При проведени опитни понижения на напорите в сондажи Л-36 и Л-37 се установяват връзка между тях, както и въздействие върху Л 1 и Л-2. Анализът на сондажните данни недвусмислено доказва бързото затъване на водоносните окарстени триаски варовици (фиг. 3) и нарастване на температурата в дълбочина (фиг. 4).

Таблица 1. Сондажи на територията на Шипковските минерални бани

Table 1. Boreholes on the territory of Shipkovo mineral baths

\begin{tabular}{|c|l|c|c|c|c|c|}
\hline Сондаж & Фирма & Година & $\begin{array}{l}\text { Дьлбочина } \\
\text { на сонда- } \\
\text { жа, } \mathrm{m}\end{array}$ & $\begin{array}{l}\text { Дьлбочина } \\
\text { на карбонат- } \\
\text { ни скали, } \mathrm{m}\end{array}$ & $\begin{array}{l}\text { Темпера- } \\
\text { тура, }{ }^{\circ} \mathrm{C}\end{array}$ & $\begin{array}{l}\text { Дебит, } \\
\text { 1/s }\end{array}$ \\
\hline $\mathrm{C}-1$ & Водоканалпроект & 1964 & 224,1 & 127 & 18 & 3,3 \\
\hline $\mathrm{C}-2$ & Водоканалпроект & 1964 & 174 & 0 & 18 & 0,2 \\
\hline С-3 & Водоканалпроект & 1965 & 215,8 & 28 & 21,2 & 31 \\
\hline Л-1 & ГПП Ямбол & 1973 & 612 & 124 & 30 & 6,4 \\
\hline Л-2 & ГПП Ямбол & 1974 & 433,5 & 133,6 & 29 & 25 \\
\hline Л-28 & ГПП Ямбол & 1982 & 230 & 60 & 19 & 3,7 \\
\hline Л-36 & ГПП Ямбол & 1983 & 1031 & 557 & 35,7 & 50 \\
\hline Л-37 & ГПП Ямбол & 1984 & 1315 & 1227 & 34,2 & 30 \\
\hline
\end{tabular}

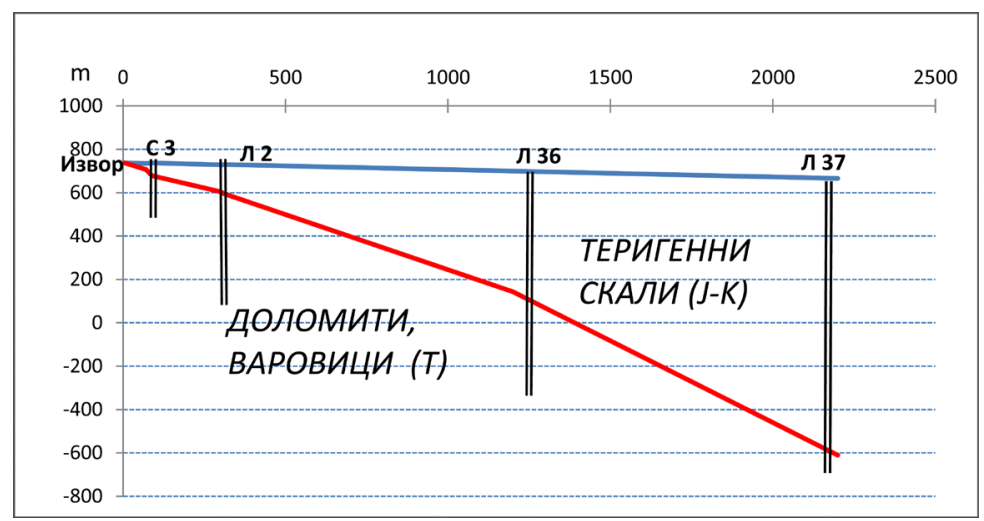

Фиг. 3. Схематичен разрез през находище „Шипково“

Fig. 3. Schematic cross-section of Shipkovo thermal water field

${ }^{2}$ Лимонадов, К. 1965. Хидрогеоложко проучване за търсене на минерална вода в Шипковските бани през 1965 г. София, ЦДА.

${ }^{3}$ Михайлов, Г. 1979. Хидрогеоложко проучване в района на Шипковските минерални бани през 1971/79 г., Национален Геофонд - V - 290.

${ }^{4}$ Михайлов, Г. 1984. Хидрогеоложко проучване в района на с. Шипково през 1982/84 г., Национален Геофонд - V - 326. 


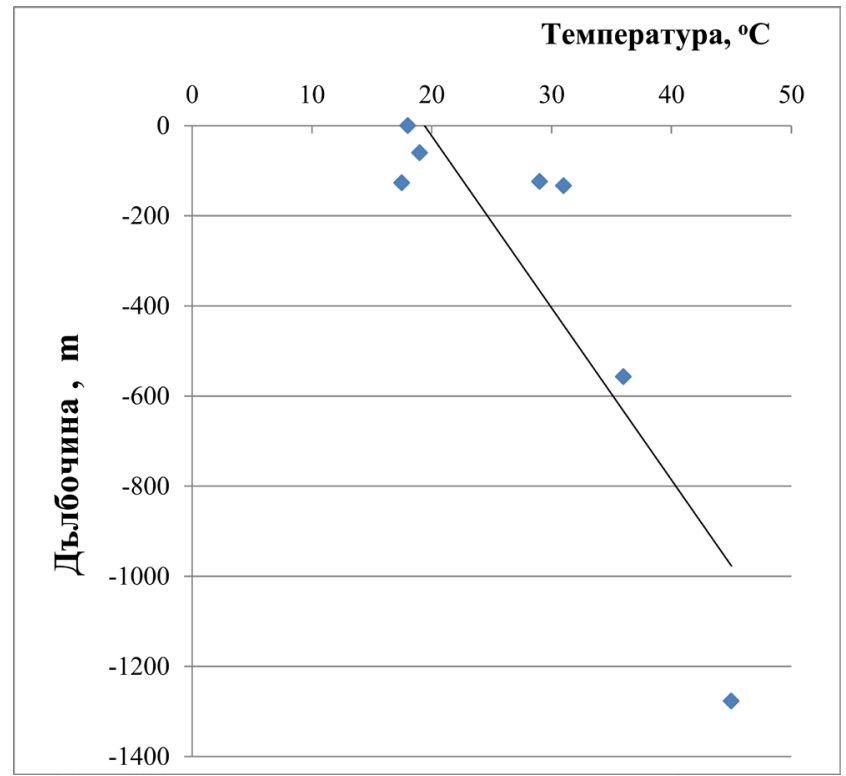

Фиг. 4. Изменение на температурата на подземните води в дълбочина за находище „Шипково“

Fig. 4. Groundwater temperature change with depth in Shipkovo thermal water

\section{Химичен състав}

Химичният състав на водите от находище „Шипково“е анализиран многократно, като публикувани данни има главно за естествения извор. Сьгласно Azmanov (1940) химичният състав на минералната вода от извора е изследван за първи път през 1903 година от А. Найденович - директор на народното здраве, а значително по-късно, през 1931 год. - от Плевенската химична лаборатория и през 1938 г. - от самия А. Азманов. Той посочва, че има съществени разлики между получените резултати от трите анализа с изключение на стойностите на сухия остатьк. Сведения за минералната вода са дадени и в обобщителните трудове за минералните води в страната на Kusitaseva, Melamed (1958), Shterev (1964), Petrov (1964), Petrov et al. (1970) и др. По време на прокарването на сондажите и разкриването на минерална вода от тях, са взимани водни проби, които са представени в съответните доклади. Най-съществен интерес представляват данните от проведените няколкократни хидрохимичини опробвания на повечето от изтичащите на самоизлив води от находищата в периода 1971-1985 г., като анализите са извършени по единна методика. Опробвани са всички водоизточници, без сондажа С-3 (общо 55 анализирани проби). От сондаж Л-1 е взета и една проба по време на сондирането за вода, която е от покриващите триаския водоносен хоризонт юрски седименти (табл. 2). Естественият извор е опробван както в сух период, когато се дренира основно минерална вода, така и при наличие на допълнително подхранване след валежи и снеготопене.

Установени са съществени разлики между отделните водоизточници, както по отношение на $\mathrm{pH}$ и обща минерализация, така и за типа на водите, характеризиращ разпределението на йонния макросъстав (табл. 2, фиг. 5).

На повечето от взетите водни проби е анализирано и съдържанието на микрокомпонентите (табл. 3). 
Таблица 2. Информация за опробваните водоизточници

Table 2. Information about sampled water sources

\begin{tabular}{|c|c|c|c|c|c|c|}
\hline \multirow{2}{*}{$\begin{array}{l}\text { Водоиз- } \\
\text { точник }\end{array}$} & \multirow{2}{*}{$\begin{array}{l}\text { Брой } \\
\text { проби }\end{array}$} & \multicolumn{2}{|c|}{ Обща минерализация, g/l } & \multicolumn{2}{|c|}{$\mathrm{pH}$} & \multirow[t]{2}{*}{ Тип на водите } \\
\hline & & $\min$ & $\max$ & $\min$ & $\max$ & \\
\hline Извор & 11 & 277 & 450,7 & 7,6 & 8,4 & $\begin{array}{l}\mathrm{HCO}_{3}-\mathrm{Ca} \\
\mathrm{HCO}_{3}-\mathrm{SO}_{4}-\mathrm{Ca}-\mathrm{Mg}\end{array}$ \\
\hline $\mathrm{C}-1$ & 3 & 1829 & 1895 & 7,4 & 7,9 & $\mathrm{SO}_{4}-\mathrm{Ca}-\mathrm{Mg}$ \\
\hline $\mathrm{C}-2$ & 6 & 1921 & 2151 & 7,2 & 8,0 & $\mathrm{SO}_{4}-\mathrm{Ca}-\mathrm{Mg}$ \\
\hline Л-1 (триас) & 7 & 512 & 731 & 6,8 & 8,3 & $\mathrm{SO}_{4}-\mathrm{HCO}_{3}-\mathrm{Ca}-\mathrm{Mg}$ \\
\hline Л-1 (юра) & 1 & \multicolumn{2}{|c|}{1229} & \multicolumn{2}{|c|}{6,8} & $\mathrm{SO}_{4}-\mathrm{Ca}-\mathrm{Mg}$ \\
\hline Л-2 & 10 & 469 & 706 & 7,5 & 7,9 & $\mathrm{SO}_{4}-\mathrm{HCO}_{3}-\mathrm{Ca}-\mathrm{Mg}$ \\
\hline Л-28 & 5 & 1784 & 1996 & 7,4 & 8,3 & $\mathrm{SO}_{4}-\mathrm{Ca}-\mathrm{Mg}$ \\
\hline Л-36 & 9 & 380 & 418 & 7,4 & 8,4 & $\begin{array}{l}\mathrm{HCO}_{3}-\mathrm{SO}_{4}-\mathrm{Ca}-\mathrm{Mg} \\
\mathrm{SO}_{4}-\mathrm{HCO}_{3}-\mathrm{Ca}-\mathrm{Mg}\end{array}$ \\
\hline Л-37 & 3 & 506 & 539 & 8 & 8,3 & $\begin{array}{l}\mathrm{HCO}_{3}-\mathrm{SO}_{4}-\mathrm{Ca}-\mathrm{Mg} \\
\mathrm{SO}_{4}-\mathrm{HCO}_{3}-\mathrm{Ca}-\mathrm{Mg}\end{array}$ \\
\hline
\end{tabular}

По време на проучванията са извършвани и анализи на газовия състав, включително и присъствие на радон в някои водоизточници от находището (табл. 4).

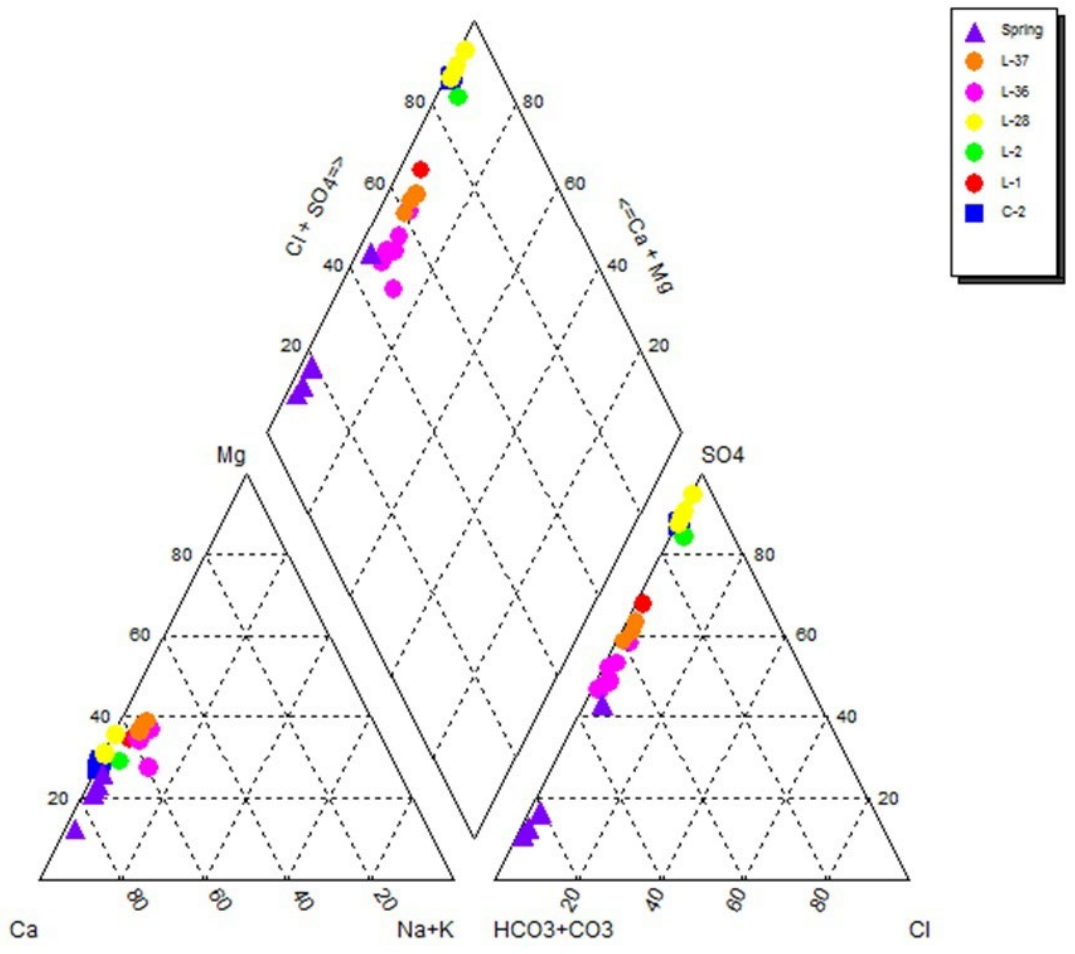

Фиг. 5. Диаграма на Пайпър

Fig. 5. Piper diagram 
Таблица 3. Установени микрокомпоненти

Table 3. Microcomponents

\begin{tabular}{|c|c|c|c|c|c|}
\hline \multirow{2}{*}{$\begin{array}{l}\text { Микроком- } \\
\text { поненти }\end{array}$} & \multirow{2}{*}{$\begin{array}{l}\text { Брой } \\
\text { проби }\end{array}$} & \multicolumn{3}{|c|}{ Характерни стойности, $\mu \mathrm{g} / 1$} & \multirow{2}{*}{$\begin{array}{l}\text { Водоизточник с установена } \\
\text { максимална стойност }\end{array}$} \\
\hline & & Средно & Мин. & Макс. & \\
\hline $\mathrm{Ag}$ & 16 & 1,7 & 0,05 & 5,6 & $\mathrm{C}-2$ \\
\hline $\mathrm{Al}$ & 41 & 692 & 101 & 1904 & $\mathrm{C}-1$ \\
\hline $\mathrm{Ba}$ & 43 & 357 & 60 & 952 & $\mathrm{C}-1$ \\
\hline $\mathrm{Be}$ & 6 & 290 & 84 & 591 & $\mathrm{C}-2$ \\
\hline $\mathrm{Ce}$ & 3 & 646 & 530 & 876 & Л-28 \\
\hline $\mathrm{Cr}$ & 7 & 3,7 & 0,3 & 12 & Л-36 \\
\hline $\mathrm{Cu}$ & 50 & 30 & 0,7 & 728 & извор \\
\hline $\mathrm{Fe}$ & 49 & 117 & 2 & 1176 & извор \\
\hline $\mathrm{Ga}$ & 3 & 0,4 & 0,2 & 0,5 & Л-37 \\
\hline $\mathrm{Ge}$ & 2 & 30 & 0,4 & 60 & Л-1 \\
\hline $\mathrm{La}$ & 3 & 264 & 177 & 350 & Л-28 \\
\hline $\mathrm{Li}$ & 42 & 412 & 29 & 2793 & C-1 \\
\hline $\mathrm{Mn}$ & 49 & 10 & 0,2 & 200 & извор \\
\hline Mo & 48 & 2,6 & 0,2 & 10 & C-1 \\
\hline $\mathrm{Ni}$ & 30 & 1,2 & 0,2 & 4,2 & Л-2 \\
\hline $\mathrm{Pb}$ & 31 & 2,6 & 0,3 & 40,9 & Л-37 \\
\hline $\mathrm{Sn}$ & 13 & 1,5 & 0,2 & 5,6 & C-1 \\
\hline $\mathrm{Sr}$ & 50 & 4751 & 113 & 19040 & $\mathrm{C}-1$ \\
\hline $\mathrm{Ti}$ & 46 & 30 & 2,4 & 409 & Л-1 \\
\hline $\mathrm{V}$ & 8 & 4,9 & 0,5 & 30 & Л-1 \\
\hline $\mathrm{W}$ & 1 & 349 & 349 & 349 & Л-1 \\
\hline $\mathrm{Zn}$ & 25 & 44 & 9,5 & 142 & Л-37 \\
\hline $\mathrm{Zr}$ & 8 & 13 & 0,5 & 53 & Л-28 \\
\hline
\end{tabular}

Таблица 4. Газове в някои водоизточници на находище „Шипково“

Table 4. Gases in some water sources at Shipkovo thermal water field

\begin{tabular}{|c|c|c|c|c|}
\hline Водоизточник & $\mathrm{H}_{2} \mathrm{~S}, \mathrm{mg} / \mathrm{l}$ & $\mathrm{CO}_{2}, \mathrm{mg} / 1$ & $\mathrm{He}, \mathrm{Pa}$ & Радон, $\mathrm{Bq} / 1$ \\
\hline извор & & & 0 & 129,5 \\
\hline $\mathrm{C}-1$ & & & & 18,5 \\
\hline $\mathrm{C}-2$ & & & 4,7 & 18,5 \\
\hline Л-1 & & & 54,1 & 18,5 \\
\hline Л-2 & 0,8 & 4 & 3,9 & 85,1 \\
\hline Л-28 & 0,2 & 9 & 2,2 & 7,4 \\
\hline Л-36 & 1,1 & 4 & 33,1 & 92,5 \\
\hline Л-37 & 0,6 & 9 & 33,1 & 77,7 \\
\hline
\end{tabular}


Съгласно Kostadinov et al. (1978), водите от находище „Шипково“ са подходящи за лечение на заболявания на нервната система, хипертонична болест, заболявания на опорно-двигателния апарат, стомашно-чревни, чернодробножлъчни, бъбречно-урологични заболявания.

\section{Дискусия}

След анализ на данните за химичния състав на водите от естествения извор и сондажите в находище „Шипково“ се установява, че той е специфичен за отделните водоизточници и се променя в различна степен във времето (табл. 2). С най-съществени колебания на концентрациите на някои хидрохимични показатели се характеризира естественият извор - максималните и минимални

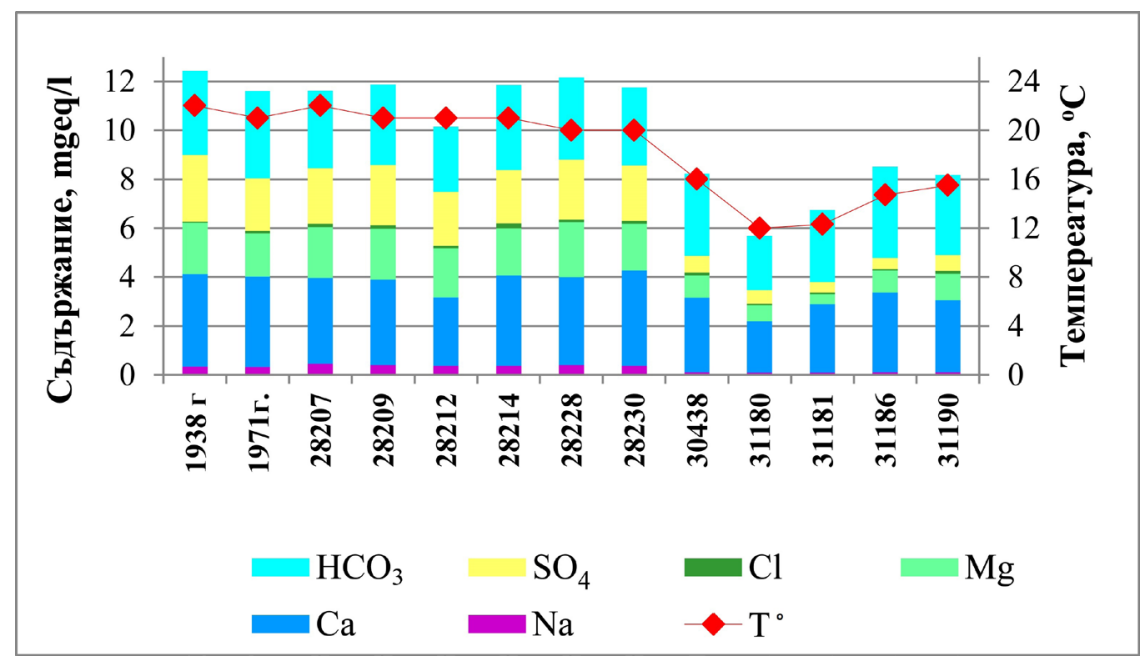

Фиг. 6. Съдържанията на основните макрокомпоненти и температура на водите в естествения извор Fig. 6. Contents of the main macro components and the water temperature in the natural spring

стойностите на общата минерализация се различават приблизително два пъти, а $\mathrm{pH}$ - с около 2 единици. Едновременно с това се променят концентрациите на основните макрокомпоненти и съотношенията между тях (фиг. 6). Установява се, че при по-ниски температури и високи дебити, във водите относително намалява съдържанието главно на сулфати и магнезий. Намалява и присъствието на натрий. Променя се типа на водите от $\mathrm{HCO}_{3}-\mathrm{SO}_{4}-\mathrm{Ca}-\mathrm{Mg}$ в $\mathrm{HCO}_{3}-\mathrm{Ca}$. По-ниските температури обикновено са свързани с по-влажни периоди, когато съществена роля в подхранването на извора имат падналите валежи върху окарстените скали във водосбора му и те разреждат изтичащите естествени минерални води, като намалява и общата минерализация. Това се потвърждава и от факта, че по време на валежни периоди и снеготопене, съществено се променят концентрациите на показатели, характеризиращи дълбочинен произход на термални води флуора (от $1,5 \div 1,6$ на $0,1 \div 0,3 \mathrm{mg} / \mathrm{l}$ ) и на метасилициева киселина (от $20 \div 25$ на $10 \mathrm{mg} / \mathrm{l})$. В периоди, в които от извора изтичат главно минерални води, а не смесени термални и валежни води, значително по-високи са концентрациите на барий, стронций, алуминий. Високи са и съдържанията на литий $(0,65 \div 1,04$ $\mathrm{mg} / \mathrm{l})$. Тогава са относително постоянни и сравнително ниски и съдържанията на желязо - между 10 и $25 \mu \mathrm{g} / 1$. При по-активно участие във формиране на оттока на извора на валежни води, вследствие на това, че те са с по-висока степен на окислително-редукционен потенциал, се увеличават разтворимите форми на 
желязото и при максимални дебити на изворите се променят, като се установяват стойности достигащи до повече от $1000 \mu \mathrm{g} / 1$.

Промени в химичния състав се наблюдават и в други водоизточници, но предвид на това, че това са сондажи, разкриващи по-дълбоко залягащи води с

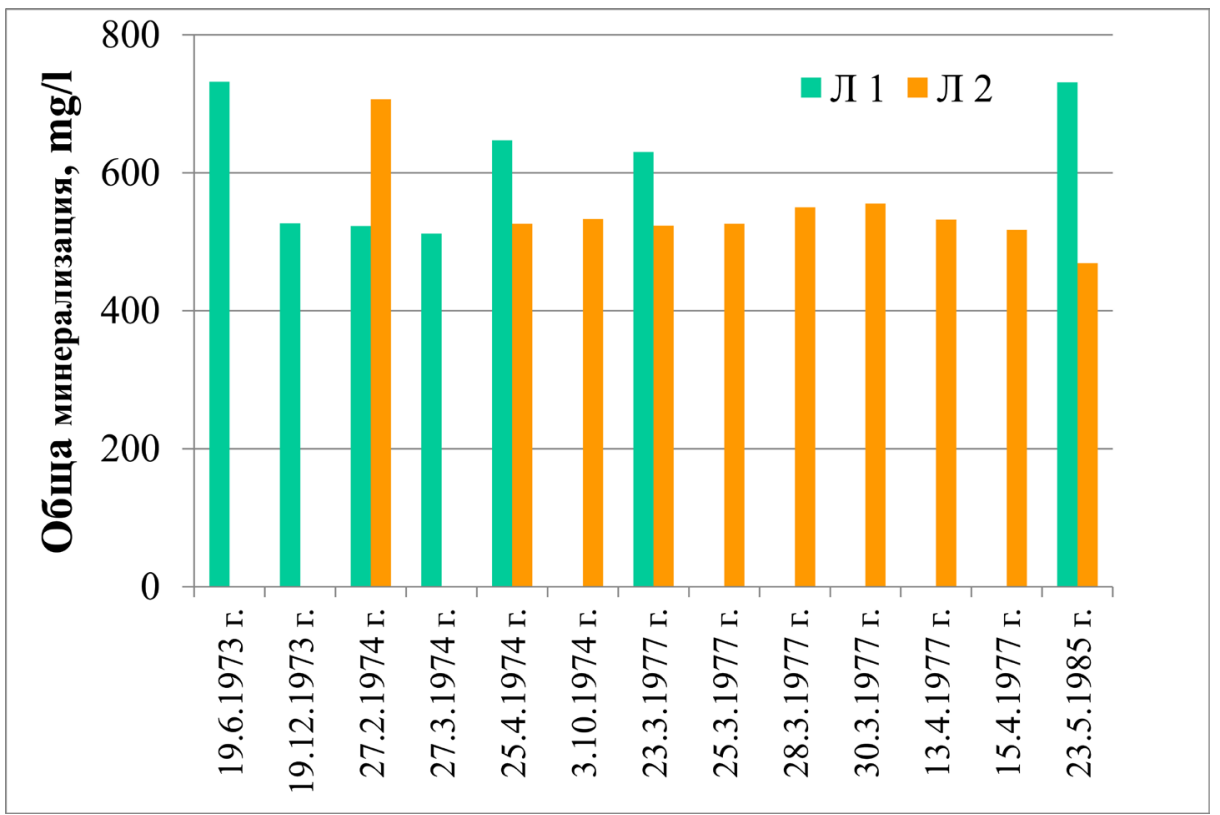

Фиг. 7. Промяна на общата минерализация в сондажите Л-1 и Л-2

Fig. 7. Change of total dissolved solids (TDS) in boreholes L 1 and L 2

относително забавен водообмен, те са по малки (табл. 2). Изключение правят само единични проби взети от сондажите Л-1 и Л-2, в които се установява краткотрайно нарастване на общата минерализация (фиг. 7). Увеличението ѝ е главно за сметка на по-високи концентрации на калций и сулфати във водите, съпътствано с по-високи съдържания на $\mathrm{Sr}, \mathrm{Al}, \mathrm{Ti}$.

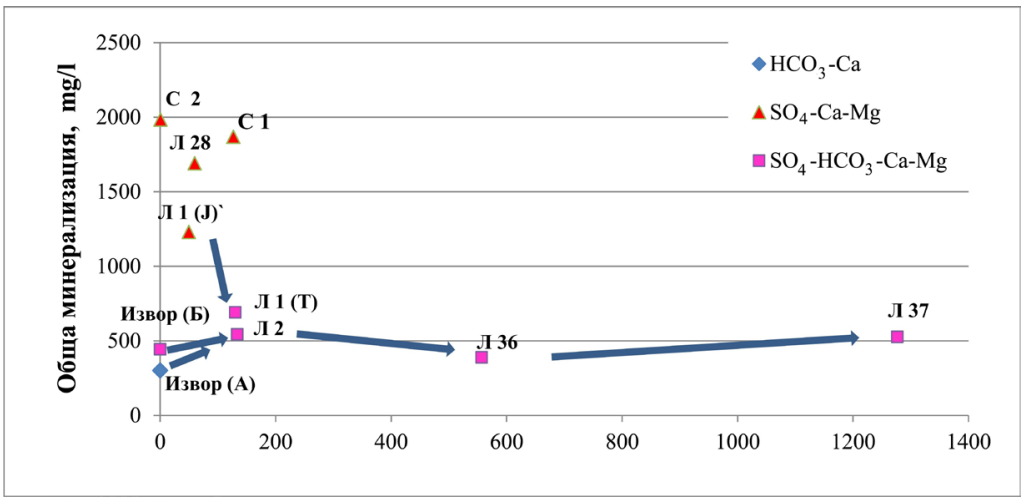

Фиг. 8. Промяна на типа на водите и общата минерализация в зависимост от дълбочината на залягане на термалните води

Fig. 8. Change of water type and TDS depending on the depth of thermal water 
Анализът на особеностите на химичния състав в отделните водоизточници показва влиянието на геоложките и хидрогеоложките фактори за неговото формиране и промени в дълбочина (фиг. 8). Смесването на водите, формирани при активен водообмен в карстовата среда на триаските варовици и доломити с $\mathrm{HCO}_{3}-\mathrm{Ca}$ и $\mathrm{HCO}_{3}-\mathrm{Ca}-\mathrm{Mg}$ тип с пукнатинните води със застоен характер в юрските наслаги и в обсега на Шипковския разлом с $\mathrm{SO}_{4}-\mathrm{Ca}-\mathrm{Mg}$ тип, се образуват характерните за естествения извор при минимално валежно подхранване и за подълбоките части на находището $\mathrm{SO}_{4}-\mathrm{HCO}_{3}-\mathrm{Ca}-\mathrm{Mg}$ води.

По отношение на микрокомпонентите се установява слаба тенденция за увеличаване на концентрацията на F, Sr, Ti, Ba, Mo, Ni, Mn в дълбочина, но в найдълбоките сондажи - Л-36 и Л-37 са относително по-ниски, отколкото в Л-28, Л-1 и Л-2. Отражение за химичния състав имат и зоните с железни орудявания в юрските скали. На тях се дължат периодично високите съдържания на желязо в естествения извор при ниски води и в сондажите С-1 и Л-36. Правят впечатление сравнително високите съдържания на $\mathrm{Al}, \mathrm{Ba}, \mathrm{Li}, \mathrm{Sr}$ във водоизточниците на находище „Шипково“.

\section{Изводи и заключение}

Находището на термоминерални води „Шипково“ е едно от най-големите в Северна България. Неговият химичен състав се формира главно за сметка на геоложките фактори. На първо място значение има окарстената филтрационна среда, като изграждащите я триаски варовици и доломити постепенно затъват в дълбочина. Роля има и смесването на тези води с относително поминерализираните такива, привързани към юрските седименти и Шипковския разлом. Направеният анализ на състава на водите в отделните водоизточници показва, че за всеки от тях на фона на общите закономерности за промените в техния макросъстав са характерни някои специфични особености, свързани с присъствието на някои микрокомкомпоненти, радиологични показатели и други. Това позволява да се вземат правилни управленски решения за оползотворяването на термалните води от находище „Шипково“.

\section{Литература}

\section{References}

Azmanov, A. 1940. Bulgarian Mineral Springs. State Printing, Sofia, 265 p. (in Bulgarian).

Bonchev, G. 1939. Contribution to the springs in Bulgaria. Journal of the Bulgarian Academy of Sciences, vol. 59, no. 30, 85-132 (in Bulgarian).

Cheshitev, G., T. Nikolov, V. Milanova, Ts. Chontova. 1993. Explanatory note to the Geological Map of the Republic of Bulgaria on Scale 1:100 000. Troyan Map sheet. Geology and Mineral Resources Committee, Enterprise of Geophysical Survey and Geological Mapping.

Cheshitev, G., T. Nikolov, V. Milanova, Ts. Chontova. 1994. Geological map of Bulgaria on Scale 1:100 000. Troyan Map sheet. Geology and Mineral Resources Committee, Enterprise of Geophysical Survey and Geological Mapping.

Gochev, P.M. 1971. Teteven anticlinorium. In: Fore-Balkan tectonics, BAS, Sofia, 229-332 (in Bulgarian).

Kostadinov, D., L. Tsvetkova, D. Karakolev, L. Vladeva, G. Zagorski, T. Karageorgiev, V. Marinov, V. Malinovska, S. Stamatov, T. Stoyanov, K. Shterev. 1976. Bulgarian resorts (Guide on resort's objects). Meditsina i Fizkultura, Sofia, 354 p. (in Bulgarian). 
Kusitaseva, V., Y. Melamed. 1958. Composition of the Bulgarian Mineral Waters. Studies on the Chemical Composition. Meditsina i Fizkultura, Sofia, 280 p. (in Bulgarian).

Nikolov, T., I. Sapunov. 1970. On the regional stratigraphy of Upper Jurassic and Lower Cretaceous in Balkanides. Comptes rendus de l'Académie bulgare des Sciences, 23, 1397-1400 (in Russian).

Petrov, P., S. Martinov, K. Limonadov, Y. Straka. 1970. Hydrogeological Study of Mineral Water in Bulgaria. Tehniка, Sofia, 196 p. (in Bulgarian).

Petrov, P. 1964. Basic regularities of the mineral water distribution in Bulgaria. Works Geology of Bulgaria, Series Eng. Geology and Hydrogeology, 3, 83-158 (in Bulgarian).

Radoslavov, B. 1937. Studying and capturing of the municipal mineral spring near Shipkovo village. Review of the Bulgarian Engineers and Architects, 6, 164-170 (in Bulgarian).

Shterev, K. 1964. Mineral Waters in Bulgaria. Nauka i Izkustvo, Sofia, 172 p. (in Bulgarian).

Tronkov, D. 1981. Stratigraphy of the Triassic System in part of the Western Srednogorie (West Bulgaria). Geologica Balcanica, 11, 1, 3-20 (in Russian).

Vutkov, V., P. Petrov. 1968. Shipkovo mineral baths. Meditsina i Fizkultura, Sofia, 52 p. (in Bulgarian).

Постьпила: 17.06.2019

Received: 17 June 2019

Приета: 11.11.2019

Accepted: 11 November 2019 
40 Geological Institute, Bulgarian Academy of Sciences (C) 